This article was downloaded by: [National Taiwan University]

On: 16 December 2008

Access details: Access Details: [subscription number 788846425]

Publisher Taylor \& Francis

Informa Ltd Registered in England and Wales Registered Number: 1072954 Registered office: Mortimer House, 37-41 Mortimer Street, London W1T 3JH, UK

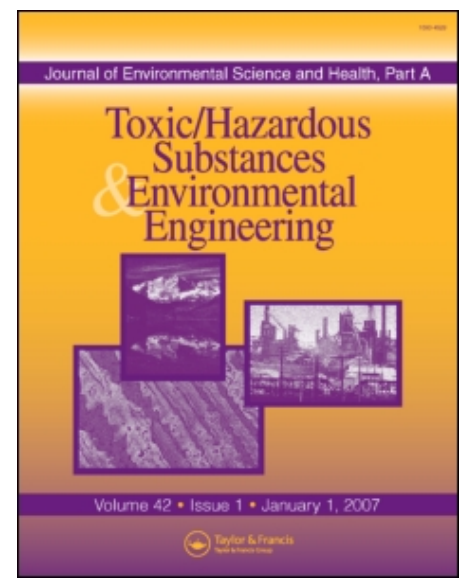

Journal of Environmental Science and Health, Part A

Publication details, including instructions for authors and subscription information: http://www.informaworld.com/smpp/title content=t713597268

\title{
Recovering Industrial Sludge-Derived Slag as Fine Aggregate
}

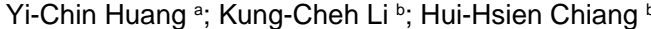

${ }^{a}$ Department of Land Management and Development, Chang Jung Christian University, Tainan, Taiwan ${ }^{b}$ Graduate Institute of Environmental Engineering, National Taiwan University, Taipei, Taiwan

Online Publication Date: 01 January 2005

To cite this Article Huang, Yi-Chin, Li, Kung-Cheh and Chiang, Hui-Hsien(2005)'Recovering Industrial Sludge-Derived Slag as Fine Aggregate',Journal of Environmental Science and Health, Part A,40:1,193 - 202

To link to this Article: DOI: 10.1081/ESE-200038482

URL: http://dx.doi.org/10.1081/ESE-200038482

PLEASE SCROLL DOWN FOR ARTICLE

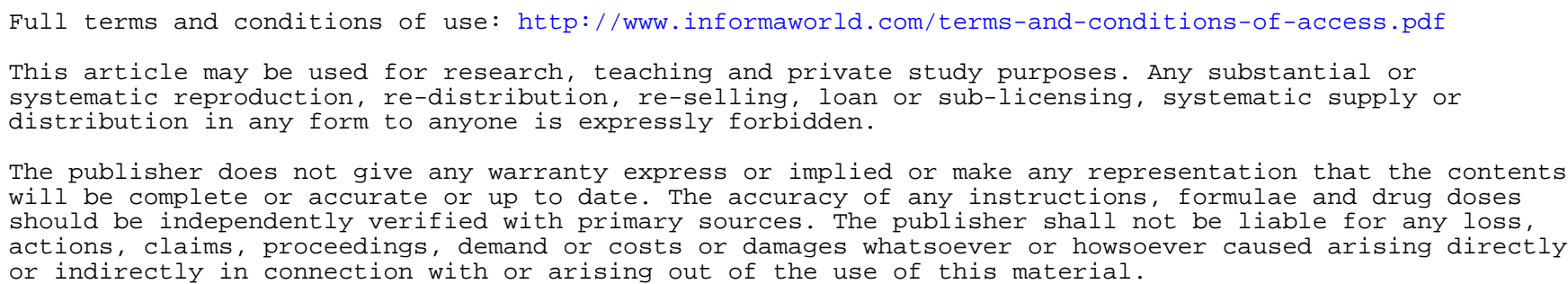




\title{
Recovering Industrial Sludge-Derived Slag as Fine Aggregate
}

\author{
Yi-Chin Huang, ${ }^{1}$ Kung-Cheh $\mathrm{Li}^{2, *}$ and Hui-Hsien Chiang ${ }^{2}$ \\ ${ }^{1}$ Department of Land Management and Development, Chang Jung Christian Univer- \\ sity, Tainan, Taiwan \\ ${ }^{2}$ Graduate Institute of Environmental Engineering, National Taiwan University, \\ Taipei, Taiwan
}

This study presents the result of using melting to recover both industrial sludge slag (the main constituent of which is calcium fluoride) and water works sludge slag as fine aggregate in cement. The main characteristics of both slag and cement mortars were measured to evaluate the feasibility of using slag as aggregate. In this study, the slag replacement ratios were $0,10,20,30,40$, and $50 \%(\mathrm{w} / \mathrm{w})$, and the curing periods were 7 , 28 , and 90 days. Slag quality was determined according to the standards of fine aggregates in the ASTM specifications, and cement mortars with various slag replacement ratios were evaluated based on their compressive strength, and Toxicity Characteristic Leaching Procedure (TCLP). The crushed slag produced in this study met the ASTM standards for fine aggregate, including gravity, unit weight, absorption, and grading, and the TCLP leached concentrations are far below existing limits, establishing the safety and suitability of slag as fine aggregate. The TCLP leached concentrations of slag and cement mortar were not significantly related to the replacement ratio, and declined with increasing curing period, revealing that the hydration strongly influenced metal leaching. The compressive strength test results of the cement mortars demonstrated that the optimal replacement ratio for maximizing compressive strength was $40 \%$. This study also discussed the effects of replacement ratio and curing periods on cement mortars.

Key Words: Sludge melting process; Calcium fluoride sludge; Waterworks sludge; Fine aggregate.

\section{INTRODUCTION}

The disposal of massive amounts of industrial sludge is a major issue in Taiwan. Presently, final disposal of industrial sludge is through landfill and

*Correspondence: Kung-Cheh Li, Graduate Institute of Environmental Engineering, National Taiwan University, Taipei, Taiwan; Fax: +886-2-23638173; E-mail: kcli@ntu.edu.tw. 
solidification. However, land limitations and widespread public resistance are creating pressure to recover sludge in constructional materials to create an alternative to landfill disposal. Industrial sludge can be recovered by several methods, including the melting process. ${ }^{[1,2]}$

The melting process is a method of recovering sludge and incorporating it into other useful materials, and has been studied and practiced for over a decade. Briefly, either limestone or silicate is added to sludge to produce a basicity (the weight ratio, $\mathrm{CaO} / \mathrm{SiO}_{2}$ ) of nearly one to obtain a relatively low temperature. ${ }^{[3-7]}$ Sludge then is furnace heated to between 1350 and $1500^{\circ} \mathrm{C}$ to melt the inorganic components and decompose the organic contents. ${ }^{[8,9]} \mathrm{Fi}$ nally, the melted material is cooled in either water or air. The sludge-derived slag can be used as a construction material for applications such as paving and aggregate. After post-melting or sintering, the slag can be formed into blocks. ${ }^{[10,11]}$ However, research on sludge melting processes in Taiwan concerned only sewage sludge, not industrial sludge.

Constituents and characteristics of industrial sludge differ according to industries and production processes. The rapid development of Taiwan's semiconductor industry has led to the production of large amounts of calcium fluoride sludge through coagulation, which is added to neutralize waste acid from wet etching, as demonstrated below:

$$
\begin{aligned}
2 \mathrm{HF}+\mathrm{Ca}(\mathrm{OH})_{2} & \rightarrow \mathrm{CaF}_{2}+2 \mathrm{H}_{2} \mathrm{O} \\
2 \mathrm{HF}+\mathrm{CaCl}_{2} & \rightarrow \mathrm{CaF}_{2}+2 \mathrm{HCl}
\end{aligned}
$$

where $\mathrm{CaF}_{2}$ becomes sludge in following sedimentation.

Calcium fluoride sludge contains high concentration of calcium fluoride (30-40\%), and low concentration of heavy metals. It is classified as general industrial waste in Taiwan. Currently, disposal of calcium fluoride sludge by landfilling has been used widely due partly to convenience. Water saturated with calcium fluoride has a fluoride concentration of $8.1 \mathrm{mg} / \mathrm{L},{ }^{[12]}$ as compared to the regulatory limitation of $0.8 \mathrm{mg} / \mathrm{L}$ for the source water of public water supply system in Taiwan, if source water has been contaminated by calcium fluoride sludge, the potential problem of fluoride-related toxicity would be increased. The solubility of calcium fluoride in stomach is higher, continued oral ingestion of calcium fluoride could produce symptoms of fluorosis. ${ }^{[12]}$ Thus, replacing limestone with calcium fluoride sludge in the melting process to provide calcium not only effectively reduces the hazard potential of calcium fluoride sludge on environment and human health, but also beneficially recovers the sludge and adjusts the basicity to facilitate cost efficient melting.

Therefore, this study aims to recover industrial calcium fluoride sludge as fine aggregate in cement, and ASTM standards were applied to evaluate the quality and properties of the sludge-derived slag and the cement mortar at various curing periods. 


\section{MATERIALS AND METHODS}

The calcium fluoride sludge was gathered from a semiconductor plant sedimentation tank. The coagulants were calcium chloride and calcium hydroxide. The gathered calcium fluoride sludge was dried at $105^{\circ} \mathrm{C}$ in an oven before the experiments were performed. After acid digestion, according to NIEA R109.01C, ${ }^{[13]}$ the main components of the sludge were determined using ICP-AES (Inductivity Coupled Plasma-Atomic Emission Spectrometer) with sensitivity in the $\mathrm{mg} / \mathrm{L}$ range.

Table 1 shows that the basicity of calcium fluoride sludge is 2.5 , indicating that silicon dioxide should be added to reduce the basicity and obtain a lower temperature. However, adding pure silicon dioxide to the sludge also increases the operational costs of the melting process, and thus co-melting with another silica-rich sludge to enable basicity regulation is a feasible method. This study used water works sludge, with a basicity of 0.001 , as an admixture. Using water works sludge as an admixture not only reduces operational temperature and cost, but also recovers the resource in sludge. Water works sludge was collected from a water treatment plant in Taipei, and dried at $105^{\circ} \mathrm{C}$ before mixing with calcium fluoride sludge. The main components of the sludge were measured using ICP-AES after acid digestion to determine the proportions of the two kinds of sludge (Table 1). The mixing proportion was set at $60 \%(\mathrm{w} / \mathrm{w})$ calcium fluoride sludge to $40 \%(\mathrm{w} / \mathrm{w})$ water works sludge to adjust basicity to 1 . Both calcium fluoride and water works sludge were ground to $0.075 \mathrm{~mm}$ before mixing.

The operational temperature during the melting process was typically determined by the pouring temperature, which was obtained via the triangular pyramid test according to JIS K 215. ${ }^{[14]}$ The slag used in this experiment was produced in a batch electro-melting furnace. After the slag was crused to a fine aggregate, the method specified in ASTM was applied to test the main slag characteristics because they affected slag application as a fine aggregate. Regarding

Table 1: Compositions of sludge and sludge-derived slag.

\begin{tabular}{|c|c|c|c|}
\hline Items & Water works sludge & $\mathrm{CaF}_{2}$ sludge & Sludge-derived slag \\
\hline $\begin{array}{l}\mathrm{CaO}(\%) \\
\mathrm{SiO}_{2}(\%) \\
\mathrm{Al}_{2} \mathrm{O}_{3}(\%) \\
\mathrm{MgO}(\%) \\
\mathrm{Fe}_{2} \mathrm{O}_{3}(\%) \\
\mathrm{Na}_{2} \mathrm{O}(\%) \\
\mathrm{K}_{2} \mathrm{O}(\%) \\
\mathrm{P}_{2} \mathrm{O}_{5}(\%) \\
\mathrm{SO}_{3}(\%) \\
\left.\text { Basicity (CaO/SiO } / \mathrm{C}_{2}\right) \\
\text { Pouring temp. }\left({ }^{\circ} \mathrm{C}\right)\end{array}$ & $\begin{array}{c}0.04 \\
47.1 \\
9.5 \\
0.7 \\
5.8 \\
0.7 \\
0.5 \\
0.5 \\
0.1 \\
0.001 \\
1,510\end{array}$ & $\begin{array}{c}55.7 \\
20.6 \\
4.9 \\
0.3 \\
\mathrm{ND} \\
0.7 \\
\mathrm{ND} \\
0.5 \\
1.5 \\
2.5 \\
1,240\end{array}$ & $\begin{array}{r}41.7 \\
39.1 \\
8.4 \\
0.6 \\
2.9 \\
0.9 \\
0.3 \\
0.6 \\
1.1 \\
1.1 \\
1,146\end{array}$ \\
\hline
\end{tabular}

$\mathrm{ND}=$ Not detected. 
the characteristics, sieve analysis was measured according to ASTM C136, ${ }^{[15]}$ slag specific gravity and absorption met the requirements ASTM C128, ${ }^{[16]}$ and the unit weight and void ratio were measured using ASTM C29. ${ }^{[17]}$

The fluidity and compressive strength of cement mortar were obtained following the method in ASTM C109. ${ }^{[18]}$ Each batch of cement mortar contained $740 \mathrm{~g}$ of cement (Portland I), $2035 \mathrm{~g}$ of fine aggregate (including sand and slag with various replacement ratios) and $370 \mathrm{~g}$ of water (water/cement ratio fixed at 0.5 ), mixed to produce nine $50 \mathrm{~mm}$ cubes. The replacement ratio of the slag was defined as the weight ratio, slag/(slag + sand). This study employed replacement ratios of $0,10,20,30,40$, and $50 \%(\mathrm{w} / \mathrm{w})$ to determine changes in the characteristics of cement mortars when part of the sand in the mortar was replaced with slag. All cubic samples were cured in an oven with constant temperature and humidity chamber $\left(23 \pm 7^{\circ} \mathrm{C}, \mathrm{RH}=95 \%\right)$ for a prespecified period $(7,28$, and 90 days) and tested in quadruplicate.

The porosities of cement mortars were analyzed using Mercury Intrusion Porosimetry (MIP). MIP was employed to measure the pore-volume and porosity of the cement mortars. After samples were vacuum-dried (at $50 \mu \mathrm{m}-\mathrm{Hg}$ ) to a constant weight, mercury was injected into the samples to determine the porevolume and porosity.

The Toxicity Characteristic Leaching Procedure (TCLP) ${ }^{[19]}$ was applied to determine the concentrations of heavy metals $(\mathrm{Cr}, \mathrm{Cu}, \mathrm{Zn}, \mathrm{Ni}, \mathrm{Mn}, \mathrm{As}, \mathrm{Pb}, \mathrm{Cd}$, and $\mathrm{Hg}$ ) in both slag and cement mortar. The tested samples were ground to $9.5 \mathrm{~mm}$, with the extraction solution of acetic acid $(\mathrm{pH}=2.9$, liquid-to-solid weight ratio $=20: 1$ ), and then rotated at $30 \pm 2 \mathrm{pm}$ for $18 \mathrm{~h}$. After filtering out solids, the TCLP extracts were analyzed using ICP-MS (Inductivity Coupled Plasma-Mass Spectrometer) with sensitivity in the ppb range.

\section{RESULTS AND DISCUSSION}

\section{Slag Characteristics}

The sludge-derived slag examined in this study appeared blackish green with luster, and its main components are $\mathrm{SiO}_{2}(39.1 \%)$ and $\mathrm{CaO}(41.7 \%)$, as listed in Table 1. Meanwhile, the total percentage of analyzed components exceeds $90 \%$. Table 2 lists the principal characteristics. In Table 2, all the main characteristics of the slag are in accordance with the ASTM specifications for fine aggregate, meaning crushed slag can be used as a fine aggregate. Furthermore, the entire TCLP leachate, including $\mathrm{Cr}, \mathrm{Cu}, \mathrm{Zn}, \mathrm{Ni}, \mathrm{Mn}, \mathrm{As}, \mathrm{Pb}, \mathrm{Cd}$, and $\mathrm{Hg}$, of the slag was below the regulatory level, and the leaching rates (leached amount/total amount of the heavy metal) approach $1 \%$. These measurement results suggest not only the environmental friendliness of the slag, but also the feasibility of the sludge melting process. 
Table 2: Characteristics of sludge-derived slag. ${ }^{a}$

\begin{tabular}{lcc}
\hline Main characteristics & Experimental results & ASTM specification \\
\hline Absorption $(\%)$ & 2.3 & $<3 \%$ \\
Unit weight $\left(\mathrm{kg} / \mathrm{m}^{3}\right)$ & 2.3 & \\
Gravity & 2.7 & $>2.5$ \\
Sieving analysis & $(\%)$ & $90-100$ \\
$<4.75 \mathrm{~mm}$ & 100 & $80-100$ \\
$<2.36 \mathrm{~mm}$ & 96 & $50-90$ \\
$<1.18 \mathrm{~mm}$ & 88 & $25-60$ \\
$<600 \mu \mathrm{m}$ & 57 & $10-30$ \\
$<300 \mu \mathrm{m}$ & 28 & $2-10$ \\
$<150 \mu \mathrm{m}$ & 9 & \\
\hline
\end{tabular}

a Mix proportion is $60 \%(\mathrm{w} / \mathrm{w}) \mathrm{CaF}_{2}$ sludge $+40 \%(\mathrm{w} / \mathrm{w})$ water works sludge.

\section{Effects of Replacement Ratio on Fluidity}

Fluidity is one of the workability, which is used to evaluate the water content of cement mortar. The standard fluidity value is in the range 105-115\% (ASTM C109), ${ }^{[18]}$ within which range cement mortar can be placed easily. Fluidity declined with increasing ratio of sludge-derived slag to fine aggregate, and Fig. 1 shows the decreasing tendency. The fluidity was $111 \%$ when the entire fine aggregate was quartz (replacement ratio 0\%), meeting the standard of fluidity, but exceeded the standard when the replacement ratio exceeded $20 \%$. Fluidity was just $90 \%$ at a replacement ratio of $50 \%$.

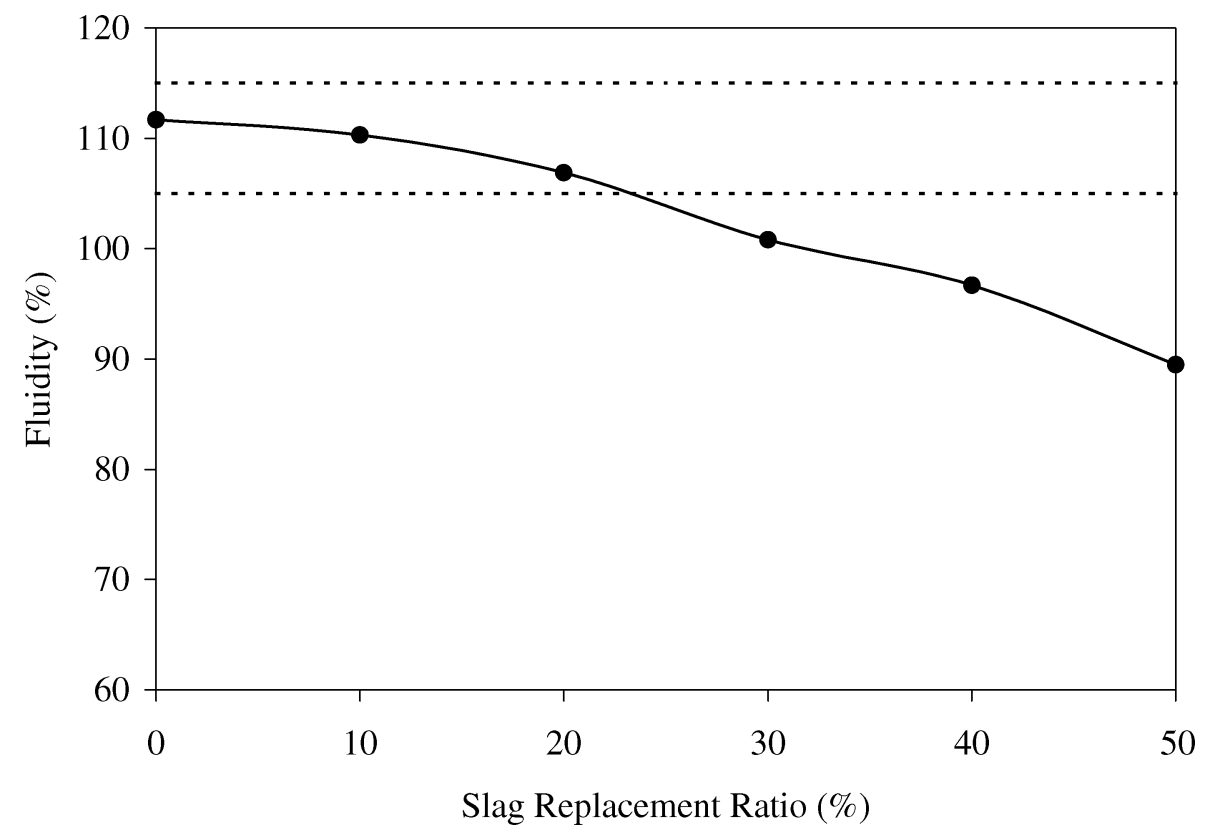

Figure 1: Effects of fluidity on cement mortars with various slag replacement ratios. 
The absorption of slag was $2.3 \%$, much higher than that of quartz sand (0.24-1.66\%), representing a reasonable result for the decreasing fluidity. Based on the point of resource recovery, if the fluidity outside of the standard range but is acceptable for placing and the later compressive strength (90-day) could reach to the safety require, the use of slag as fine aggregate still could be considered.

\section{Effects of Replacement Ratio on Compressive Strength}

Compressive strength is a key property that establishes the engineering quality of a construction material. Figure 2 illustrates the relationships among replacement ratio, curing period $(7,28$, and 90 days) and compressive strength. With increasing replacement ratio, the compressive strength increases to a certain value and then declines. For the seven-day curing period, the peak compressive strength lies at $30 \%$ replacement ratio, compared to $40 \%$ replacement ratio for the 28-day and 90-day curing periods.

The experimental results obtained from various curing periods show that the compressive strengths of the cement mortars increased with curing periods. Compressive strength was lowest at a replacement ratio of $0 \%$. The higher compressive strengths of 132 and $112 \mathrm{~kg} / \mathrm{cm}^{2}$ occurred for the 28 - and 90 -day samples, and represented 39 and $26 \%$ improvements, respectively. The decline in strength after 28 days resulted from slowdown of the later hydration reaction.

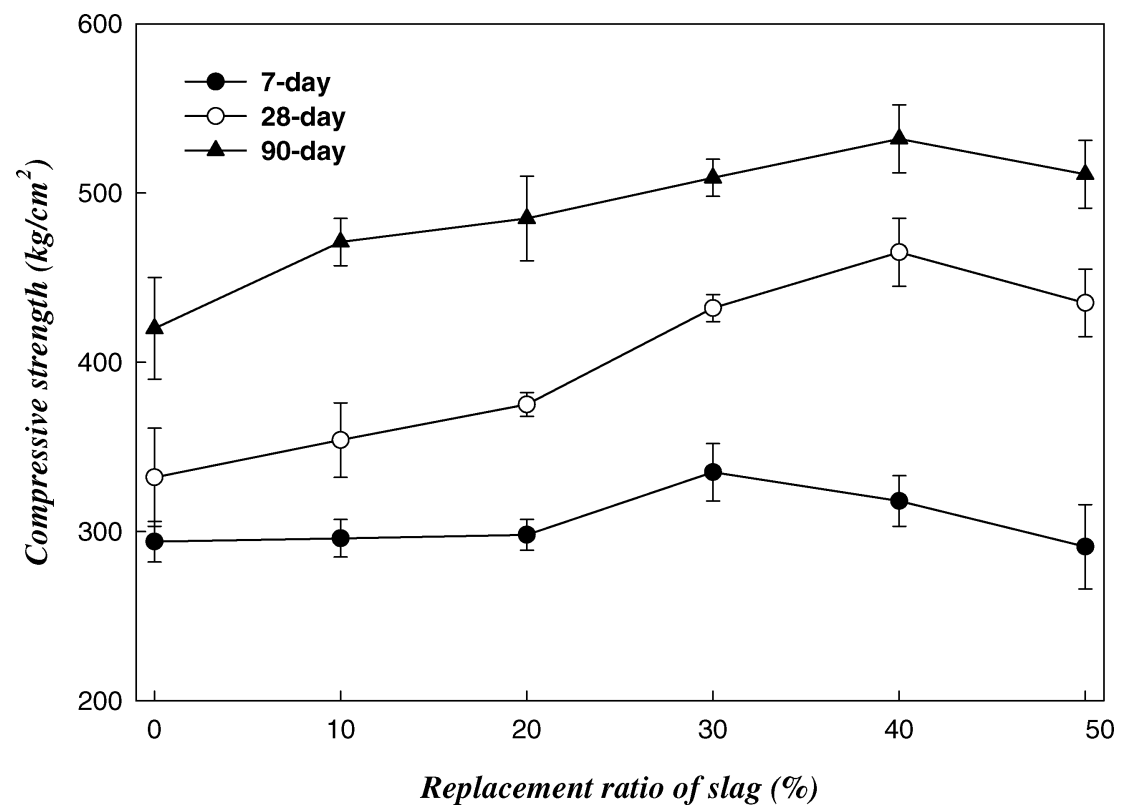

Figure 2: Effects of compressive strength on cement mortars with various curing periods and slag replacement ratios. 
Regarding applicability to engineering, Fig. 2 also demonstrates that the optimal replacement ratio is $40 \%$ when slag is applied as fine aggregate. The ratio $40 \%$ was choice not only because its seven-day compressive strength has no differ from that with $0 \%$ replacement, but also enhanced later strength (90-day) of cement mortars. However, the initial compressive strength (seven-day) for $40 \%$ replacement does not differ from that with $0 \%$ replacement. Consequently, the replacement ratio for an early strength required for engineering can be $30 \%$, since this ratio not only provides high early strength, but also enhanced later strength beyond the 28-day curing period.

\section{Effects of Replacement Ratio and Periods on Porosity}

The porosity of the cement mortars was measured using MIP with a detection limit of $0.003 \mu \mathrm{m}$. Total pore-volume was defined as the sum of gel pore volume $(<0.01 \mu \mathrm{m})$ plus capillary pore volume $(>0.01 \mu \mathrm{m})$. The experimental results (Fig. 3) demonstrate that the pore-size distribution of cement mortars was between 0.1 and $10 \mu \mathrm{m}$, with capillary pore being the main type. During the seven days of curing, the total pore-volume peaked at a replacement ratio of $0 \%(0.11 \mathrm{~mL} / \mathrm{g})$. The total pore-volume of the cement mortars decreased with increasing replacement ratio until the replacement ratio reached $30 \%$ $(0.08 \mathrm{~mL} / \mathrm{g})$. Above $30 \%$, the total pore-volume increased, but to a value lower than at $0 \%$ replacement ratio. The measured results for the 28 -day and sevenday curing periods were similar. The total pore-volume of the cement mortars peaked at a replacement ratio of $0 \%(0.09 \mathrm{~mL} / \mathrm{g})$. As the replacement ratio

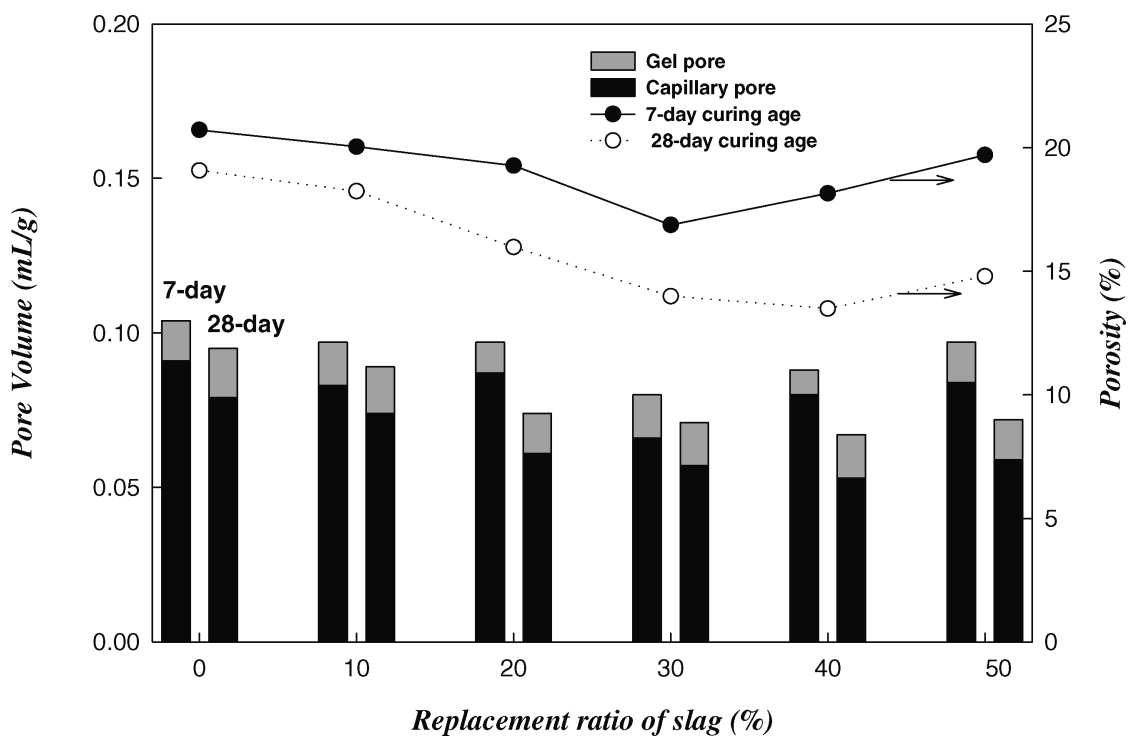

Figure 3: Effects of total pore volume (porosity) for various curing periods and slag replacement ratios. 
Table 3: Toxicity characteristic leaching procedure (TCLP) test of cement mortars for $7-, 28-$, and $90-$ day curing periods.

\begin{tabular}{|c|c|c|c|c|c|c|c|}
\hline \multirow{2}{*}{$\begin{array}{c}\text { Slag } \\
\text { replacement } \\
\text { ratio }(\%)\end{array}$} & \multicolumn{6}{|c|}{ Leached concentration $(\mu \mathrm{g} / \mathrm{L})$} & \multirow{2}{*}{$\underset{\mathrm{mg} / \mathrm{L}}{\text { TCLP standard }}$} \\
\hline & $\mathbf{0}$ & 10 & 20 & 30 & 40 & 50 & \\
\hline \multicolumn{8}{|l|}{$\mathrm{Cr}$} \\
\hline $\begin{array}{l}7-\text { day } \\
28 \text { day } \\
90 \text { day }\end{array}$ & $\begin{array}{l}440 \\
280 \\
230\end{array}$ & $\begin{array}{l}390 \\
250 \\
220\end{array}$ & $\begin{array}{l}470 \\
280 \\
230\end{array}$ & $\begin{array}{l}520 \\
310 \\
230\end{array}$ & $\begin{array}{l}320 \\
190 \\
170\end{array}$ & $\begin{array}{l}310 \\
200 \\
210\end{array}$ & 5.0 \\
\hline \multicolumn{8}{|l|}{$\mathrm{Ni}$} \\
\hline $\begin{array}{r}7-d a y \\
28 \text { day }\end{array}$ & $\begin{array}{l}70 \\
60 \\
<1\end{array}$ & $\begin{array}{r}60 \\
60 \\
4\end{array}$ & $\begin{array}{l}50 \\
50 \\
<1\end{array}$ & $\begin{array}{r}80 \\
60 \\
2\end{array}$ & $\begin{array}{r}60 \\
50 \\
5\end{array}$ & $\begin{array}{l}60 \\
50 \\
<1\end{array}$ & $--a$ \\
\hline
\end{tabular}

aNo regulatory limits in Taiwan.

increased, the minimal value occurred at $40 \%$, beyond which total pore-volume increased, but remained lower than that with a $0 \%$ replacement ratio. Figure 3 also demonstrates that the porosity (void volume/sample volume) decreased with increasing curing period. For example, at a replacement ratio of $30 \%$, the porosity for the seven-day curing period was $16.9 \%$, changing to $13.5 \%$ for the 28 -day curing period, representing a $20 \%$ decrease in porosity.

\section{Leaching of Cement Mortars}

Heavy metal leaching concentrations were measured to determine the environmental safety of using slag as fine aggregate in cement. Slag TCLP leaching test indicated that heavy metal leaching rates were far below $1 \%$, except for $\mathrm{Cr}$ (1.02\%) and $\mathrm{Ni}(1.53 \%)$. Thus, leaching tests of cement mortars were focused on $\mathrm{Cr}$ and Ni (Table 3). According to Table 3, the heavy metal leaching concentrations were not significantly correlated with the replacement ratio. After a seven-day curing period, the metal extracted with the highest concentration was $\mathrm{Cr}$ ( $>300 \mathrm{ppb}$ ), followed by $\mathrm{Ni}(40-80 \mathrm{ppb})$. After a 28 -day curing period, the metal extracted with highest concentration was still $\mathrm{Cr}$ (190-310 ppb), again followed by $\mathrm{Ni}$ (50-60 ppb). Finally, after a 90 -day curing period, the metal extracted with the highest concentration was still $\mathrm{Cr}$ (about $200 \mathrm{ppb}$ ), but the leaching concentrations of metals were below the detection limit. All leached metal concentrations were well within TCLP regulations (NIEA R201.12C). ${ }^{[19]}$

The results also show that the metal leaching concentrations declined with extended curing period, suggesting that hydration positively influences heavy metal fixing in cement.

\section{CONCLUSIONS}

After crushing, sludge-derived slag (made from $60 \%$ industrial calcium fluoride sludge and $40 \%$ water works sludge) completely met the ASTM specifications for 
fine aggregate. The leaching concentrations of heavy metals were significantly lower than the regulatory limitations for TCLP extractions for hazard waste. Total pore-volumes reduced, and the compressive strength of the cement mortar increased with increased curing period. The compressive strengths indicated that the optimal replacement ratio of slag in cement mortars was $40 \%$. The main properties of sludge-derived slag, made from mixing industrial calcium fluoride sludge and water works sludge, and of the cement mortars both suggest that sludge-derived slag used as fine aggregate is recoverable. Thus, after melting, sludge-derived slag can be converted into useful products.

\section{ACKNOWLEDGMENT}

The authors would like to thank the National Science Council of the Republic of China, Taiwan for financially supporting this research under contract No. NSC 89-2211-E-002-079.

\section{REFERENCES}

1. Sakai, S.; Hiraoka, M.; Takeda, N. Sewage sludge melting process. Water Sci. Technol. 1990, 22 (12), 329-338.

2. Yashiki, D.; Murakami, T. Operational results of melting system for sewage sludge. Water Sci. Technol. 1991, 23 (10/12), 1773-1781.

3. Murakami, T.; Ishida, T.; Sasabe, K.; Sasaki, K.; Harada, S. Characteristics of melting process for sewage sludge. Water Sci. Technol. 1991, 23 (10/12), 2019-2028.

4. Wang, K.S.; Shao, B.C. Treatment of Ashes From Municipal Solid Waste and Sewage Sludge Incinerator byMelting Process, Proceedings of the 8th Conference on Waste Management Technology in Republic of China, Tainan, Nov 28-29, 1993; 351-370.

5. Chen, H.M.; Ouyang, C.F. The characteristics of melting process on sewage sludge cake. J. Chin. Inst. Environ. Eng. 1993, 3 (3), 169-177.

6. Nishino, J.; Tahara, K. Melting properties of bottom and fly ashes derived from incineration of municipal waste (in Japanese). J. Ceramic Society of Japan 1998, 106 (11), 1117-1123.

7. Huang, Y.C.; Li, K.C. Effect of reducing condition on sludge melting process. Chemosphere 2003, 50 (8), 1063-1068.

8. Oku, S.; Kasai, T.; Takeda, N. Melting system for sewage sludge. Water Sci. Technol. 1990, 22 (12), 319-327.

9. Ohshima, Y.; Masuta, T. Sludge melting process. Water Sci. Technol. 1991, 23 (7), 68-71.

10. Endo, H.; Nagayoshi, Y.; Suzuki, K. Production of glass ceramics from sewage sludge. Water Sci. Technol. 1997, 36 (11), 235-241.

11. Wiebusch, B.; Seyfried, C.F. Utilization of sewage sludge ashes in the brick and tile industry. Water Sci. Technol. 1997, 36 (11), 251-258.

12. Fluorine compounds, inorganic, calcium. Kirk-Othmer Encyclopedia of Chemical Technology; John Wiley \& Sons, Inc.: Canada, 2003, http://www3.interscience. wiley.com/cgi-bin/mrwhome/104554789/HOME (accessed Jun 2004). 
13. Environmental analysis method. NIEA R109.01C Methods of Digestion on Sludge and Sedimentation; Environmental Analysis Laboratory of Environmental Protection Agency: Taiwan, 2001, www.niea.gov.tw (accessed May 2002).

14. JIS Year Book 2003. JIS K 2151 Coke-Testing Methods; Japanese Standards Association: Japan, 1993, www.jsa.or.jp (accessed May 2003).

15. Annual Book of ASTM Standards. ASTM C136-01 Standard Test Method of Sieve Analysis of Fine and Coarse Aggregates; ASTM International: West Conshohocken, PA, 2001, www.astm.org (accessed Jan 2004).

16. Annual Book of ASTM Standards. ASTM C128-01 Standard Test Method for Density (Specific Gravity), and Absorption of Fine Aggregates; ASTM International: West Conshohocken, PA, 2001, www.astm.org (accessed Jan 2004).

17. Annual Book of ASTM Standards. ASTM C29M-97 Standard Test Method for Bulk Density (Unit Weight) and Voids in Aggregate; ASTM International: West Conshohocken, PA, 1997, www.astm.org (accessed Jan 2004).

18. Annual Book of ASTM Standards. ASTM C109 Standard Test Method for Compressive Strength of Hydraulic Cement Mortar; ASTM International: West Conshohocken, PA, 2002, www.astm.org (accessed Jan 2004).

19. Environmental Analysis Method. NIEA R201.12C Toxicity Characteristic Leaching Procedure of Industrial Waste; Environmental Analysis Laboratory of Environmental Protection Agency: Taiwan, 2001, www.niea.gov.tw (accessed May 2002).

Received May 2, 2004 